\title{
Conservative dentistry: non-beveled esthetic restorations in anterior teeth
}

\author{
Odontologia conservadora: restaurações estéticas sem bisel em dentes anteriores
}

Lisia Lorea VALENTE ${ }^{1}$

Eliseu Aldrighi MÜNCHOW'

Sonia Luque PERALTA ${ }^{1}$

Niélli Caetano de SOUZA²

\begin{abstract}
The pursuit of esthetic excellence in dentistry today requires dental practitioners to enhance their knowledge and technique in restorations of the anterior teeth. Due to the high incidence and prevalence of fractures in this dental area, mimicking the optical properties and characteristics of the dental structure in young patients (aged 6 to 15 years) is a major challenge. This case report describes the minimally invasive, nonbeveled restoration of two fractured anterior teeth (class IV). After diagnosing fractures of teeth 11 and 21 in a 10-year-old patient, a composite mock-up was performed, followed by a diagnostic wax-up. With the aid of a silicon guide, the restorations were prepared without beveling the enamel surface. We performed color stratification by using different types of composite resins. Finally, finishing and polishing procedures were carried out.
\end{abstract}

Indexing terms: Composite resins. Dental esthetics. Tooth fractures.

\section{RESUMO}

A busca da excelência estética na odontologia atual exige, por parte do cirurgião-dentista, o aprimoramento de seus conhecimentos e técnicas para a confecção de restaurações em dentes anteriores. Em razão da alta incidência e prevalência de fraturas nesta região dentária, o desafio de mimetizar as propriedades e características ópticas da estrutura dental em pacientes jovens (entre 6 e 15 anos) torna-se um desafio. 0 presente caso clínico relata a restauração minimamente invasiva, sem utilização de bisel, na superfície dentária de duas classes IV. Após a constatação de fratura nos elementos 11 e 21 do paciente com 10 anos, realizou-se o ensaio restaurador do mesmo, com posterior moldagem e enceramento diagnóstico. A partir da confecção do guia de silicone, confeccionaram-se as restaurações através da técnica da muralha e posteriormente foi realizada a estratificação de cores mediante o uso de diferentes tipos de resina composta. Finalmente, realizaram-se os procedimentos de acabamento e polimento.

Termos de indexação: Resinas compostas. Estética dentária. Fraturas dos dentes.

\section{INTRODUCTION}

Tooth fracture is a highly prevalent event among children, especially in boys ${ }^{1}$. The incisal third of the central anterior teeth is the most frequent area impacted during accidental fractures, mainly due to the protrusive and anterior nature of these teeth. Rehabilitation of the esthetics, shape, and function of fractured teeth can pose a challenge to the dental practitioner².

Mimicking the natural characteristics of the teeth has been always considered one of the major concerns of dental professionals. Taking into consideration that good esthetics are usually the main purpose of restorative dental treatments ${ }^{3}$, the final quality of the restoration may depend on various factors, including the preparation of a bevel on the dental surface in order to hide the transition between tooth and restorative material ${ }^{4}$ as well as the proper selection of materials and shades, which may vary according to the tooth area to be restored ${ }^{5}$.

For several years, beveling of the cavosurface margin was considered essential for the preparation of esthetically successful, imperceptible restorations. Nevertheless, enamel beveling usually produces excessive substrate removal; this, in turn, could be considered an unnecessary procedure, as non-beveled esthetic restorations can also be easily obtained and thus represent the more conservative treatment option. Another important aspect to be considered during the restoration of permanent teeth is shade selection, since

\footnotetext{
${ }^{1}$ Universidade Federal de Pelotas, Faculdade de Odontologia, Departamento de Dentística. Rua Gonçalves Chaves, 457, Centro, 96015-560, Pelotas, RS, Brasil. Correspondência para / Correspondence to: EA MÜNCHOW. E-mail: <eliseumunchow@hotmail.com>

${ }^{2}$ Centro Universitário Franciscano. Santa Maria, RS, Brasil.
} 
natural teeth are polychromatic, unlike direct restorative materials (e.g., composite resins), which are commonly monochromatic. This optical mismatch may constitute an obstacle to the achievement of an excellent esthetic outcome when using only one shade of resin composite ${ }^{6}$. Consequently, the "primary" (i.e., hue, chroma, and value) and "secondary" (i.e., fluorescence, opalescence, translucency, and opacity) optical characteristics of restorative materials should be properly observed in an attempt to ensure satisfactory treatment ${ }^{7}$.

Within this context, the purpose of the present article was to report the restorative treatment of two fractured permanent teeth without beveling of the dental substrate and using a combination of different resins and shades in order to restore the natural appearance of the teeth.

\section{CASE REPORT}

N.L.D.V.P., a 10-year-old Caucasian male, was brought to the Dental Clinic of Centro Universitário Franciscano (UNIFRA) with a chief complaint of fracture of both maxillary central incisors (11 and 21). After obtaining written informed consent from the patient's mother, a history and intraoral examination were performed and revealed two class IV cavities. Tooth 11 was fractured in the enamel only, whereas both enamel and dentin were involved in tooth 21 (Figure 1).

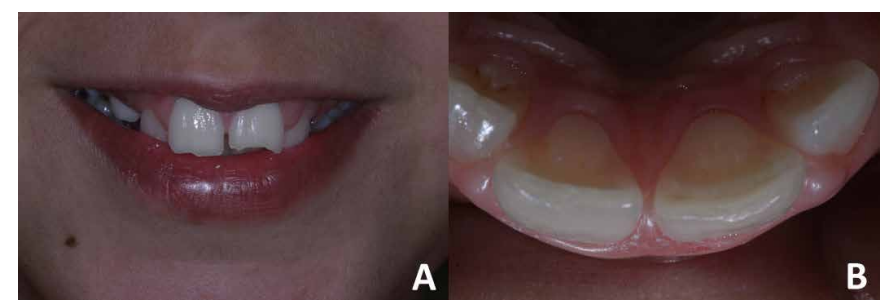

Figure 1. Fractures of teeth 11 and 21 (A). The fracture of tooth 11 involved only enamel, whereas in tooth 21, both enamel and dentin were involved (B).

As that the teeth fragments were missing, the suggested treatment option was a composite restoration. First, impressions from the maxillary and mandibular arches were obtained for a subsequent diagnostic waxup. Next, the shade of the teeth was selected using the Vita shade guide, followed by temporary restoration of both teeth (mock-up) using the stratified technique (i.e., different types and shades of resin composites). Briefly, AdperTM Single Bond Plus Adhesive (3M ESPE, St. Paul, MN, USA) was applied, without previous acid etching of the teeth, followed by application of compressed air for solvent removal and light-activation for 20 seconds (s). Resin composites (Filtek Supreme XT, 3M ESPE; and Four Seasons, Ivoclar Vivadent, Schaan, Liechtenstein) of different shades and translucency/opacity ratios were applied and light-activated for $20 \mathrm{~s}$.

Before the next clinical appointment, a diagnostic wax-up was performed on the plaster models obtained and a silicone impression was taken for further use as a guide for the permanent restoration of teeth 9-10. To that end, the temporary restorations were removed and the anterior area was isolated with cotton rolls and gingival retraction cord. Next, 37\% phosphoric acid was applied (Figure 2a) for $30 \mathrm{~s}$ and $15 \mathrm{~s}$ on enamel and dentin, respectively. The teeth were then rinsed with water for $30 \mathrm{~s}$ and dried with absorbent paper points. The dentin was kept moist. Single Bond was then applied (Figure 2b), followed by solvent removal using compressed air and light-activation for $20 \mathrm{~s}$ (Figure 2c).

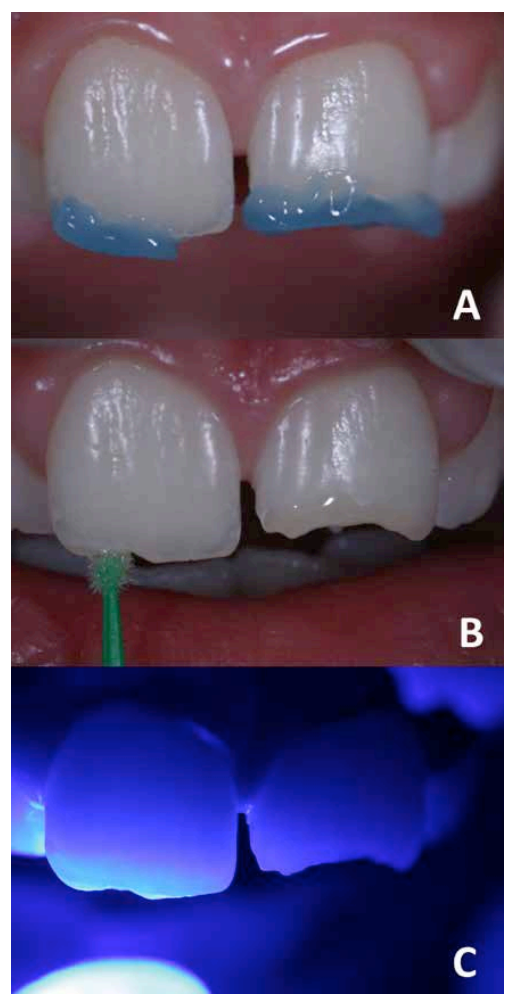

Figure 2. Acid etching of the fractured teeth with $37 \%$ phosphoric acid $(A)$. Application of the Adper ${ }^{\mathrm{TM}}$ Single Bond Plus Adhesive (B), followed by light-curing (C).

Subsequently, the silicone guide, which had been previously cut into two halves, was placed on the back of the anterior teeth. Tooth 11 was restored using Filtek Supreme XT, shade $\mathrm{YT}$, in the palatal area (Figure 3a) and Four Seasons, shades T. Blue and B1E, in the incisal area and buccal surface, respectively (Figure $3 \mathrm{~b}$ ). Tooth 21 
was restored using the aforementioned composites, as well as Four Seasons, shade B1D, for reconstruction of the dentinal mamelons (Figure 3c). The last layer of resin composite was applied with a brush so as to hide the transition between substrate and material (Figure $3 \mathrm{~d}$ ). Each composite increment was light-cured for $20 \mathrm{~s}$.

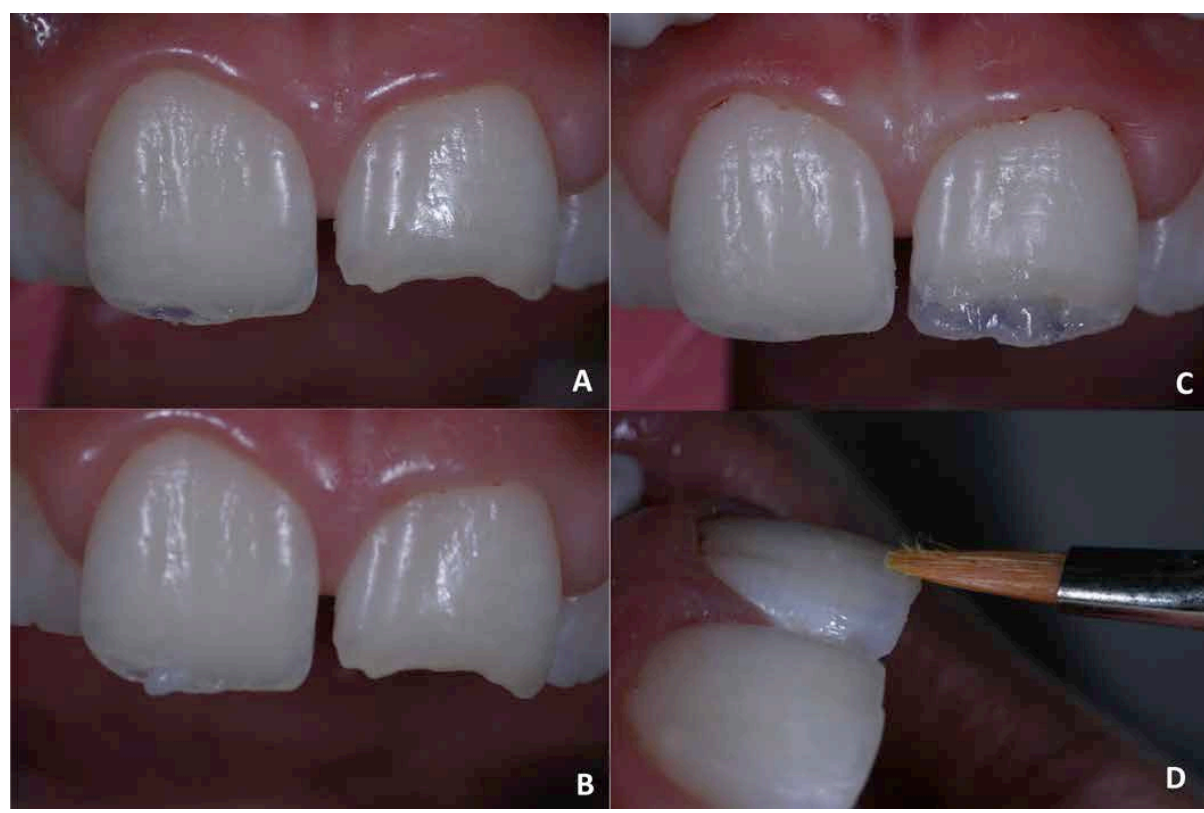

Figure 3. Restoration of tooth 11 by layering of translucent and enamel composites to reestablish the palatal (A) and buccal (B) surfaces, respectively. Restoration of tooth 21 by combining translucent, enamel and dentin resin composites. The dentinal mamelons were reproduced by using dentin material with greater opacity (C). Application of a composite brush to smooth the upper layers of material (D)

An occlusal test was performed using carbon paper. Next, finishing and polishing procedures were performed using the Sof-Lex TM Finishing and Polishing System (3M ESPE) (Figure 4). The enamel perikymata were reproduced by drawing small transverse ridges on the surface of the teeth with the aid of a diamond bur (2135FF, KG Sorensen, Cotia, Brazil) (Figure 5a). To facilitate visualization of the final texture, a fine silver powder was applied to the buccal surface of the teeth (Figure 5b,c). One day later, the restorations were polished with a felt disc and diamond paste (Diamond Flex, FGM, Joinville, Brazil). Figure 6 shows the final appearance (after 1 week) of the restorations: frontal (a), lateral (b), incisal (c), and smile (d) views.

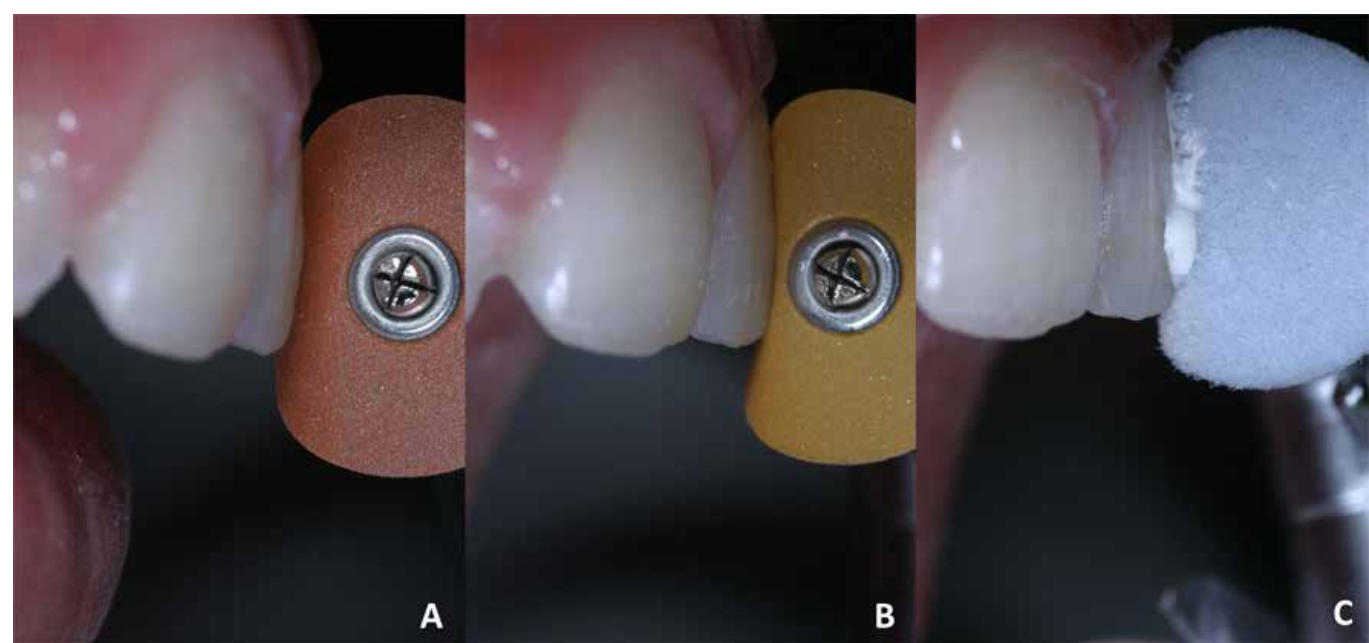

Figure 4. Finishing procedure performed using the Sof-Lex ${ }^{\top M}$ Finishing and Polishing System (A and B) and polishing procedure using a felt disc and diamond paste (C). 


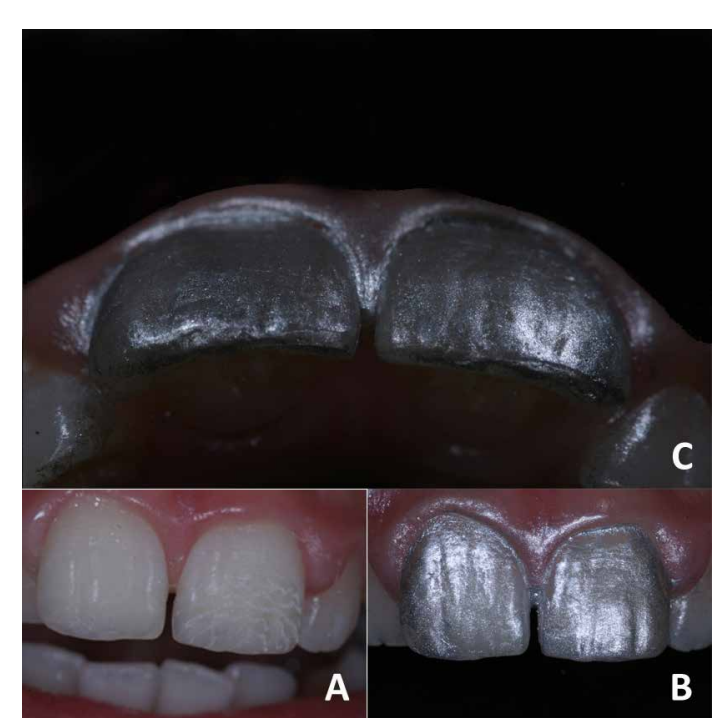

Figure 5. Preparation of perikymata on the buccal surface of tooth 21 to mimic the appearance of natural teeth (A). Application of silver powder on the surface of the restored teeth in an attempt to facilitate visualization of the texture produced ( $B$ and $C$ ).

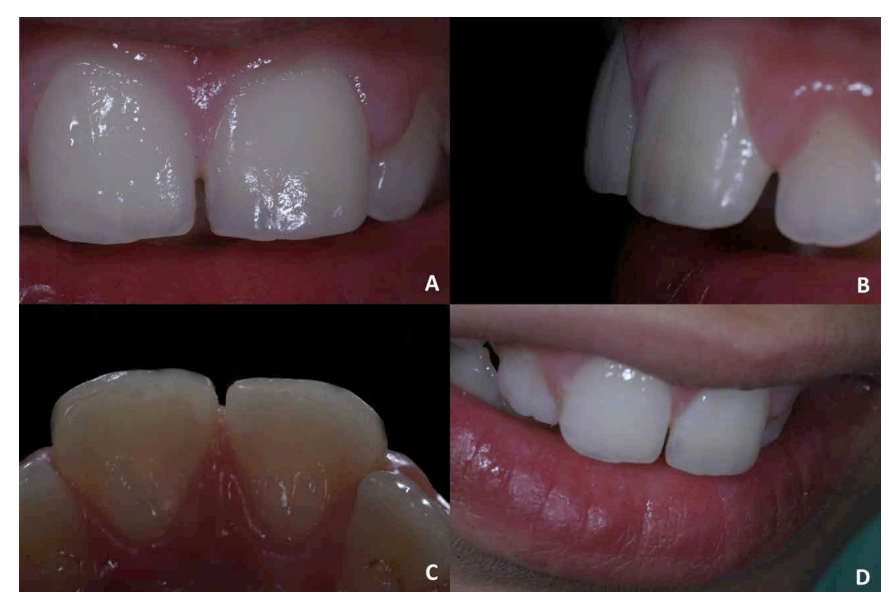

Figure 6. Final images, after 1 week, of the restorative treatment performed: frontal (A), lateral (B), incisal (C) views, and smile of the patient (D).

\section{DISCUSSION}

Coronal fractures of the permanent teeth are very common in young individuals, and mainly involve the anterior area of the maxillary teeth ${ }^{8-11}$. Regardless of cause, tooth fractures compromise masticatory function, the health of oral tissues, and the smile esthetic. With the advent of the adhesive dentistry, dental esthetic restorative treatments became easier and faster. Moreover, the use of resin composites enables a more conservative treatment, with minimal removal of remaining dental structures. Although the first choice for fracture restoration is bonding of the original fractured fragment back onto the tooth, which may restore the natural characteristics (color, translucency, shape, and texture) of the tooth, the fragments were missing in the present case, thus ruling out this treatment option.

Despite several available techniques, direct composite restoration is a conservative alternative. In addition, taking into account the young age of the patient and subsequent incomplete maturation of his maxillary bones, composite restoration constituted the best option for rehabilitation of the esthetic problem presented ${ }^{12-13}$ Even though the bevel technique is still widely used in the clinic $^{14}$, especially because dental practitioners believe it prevents marginal leakage and leads to better retention of the restorative material ${ }^{15-16}$, countless restorations have been performed without beveling the substrate. Indeed, excellent esthetic and functional results can be achieved using the non-beveled technique, and its use precludes administration of anesthesia, thus producing less discomfort to the patient. Therefore, the restoration of both teeth in the present case was performed without beveling the substrate.

Among the various factors that influence the appearance of a restoration, correct shade-matching and successful simulation of the anatomical shape are by far the major concerns of treatment ${ }^{13}$. As shown in Figure 6, the restorative treatment performed yielded a satisfactory esthetic outcome, confirming that substrate beveling is not essential. It bears noting that a very conservative treatment was obtained with the technique described.

The use of a silicone guide to build up the palatal surface of anterior teeth makes the restorative process easier ${ }^{9}$. In the present case, the silicone guide was obtained from the diagnostic wax-up. Although this technique involves a laboratory stage, the patient's chair time during the restoration procedure is usually lower as compared to the conventional technique (i.e., without the silicone buildup guide $)^{17}$.

The esthetic result obtained in this case was also dependent on the stratification technique performed, since the combination of different color shades and resin composites of distinct translucency/opacity was used to mimic the natural appearance of the teeth. Indeed, translucent incisive halos as well as opaque mamelons could be restored. In addition, the nanofilled composite materials used led to an optimal polished, smooth surface, thus contributing to the esthetic outcome of the restorations ${ }^{18}$. 


\section{CONCLUSION}

Current practice in operative dentistry advocates that, regardless of the procedure, dental practitioners should choose the most conservative treatment modality. Taking this into account, the present case report outlined the restoration of two coronal fractures involving the maxillary central incisors without substrate beveling. The esthetic quality of the restoration was considered satisfactory and was approved by the patient.

\section{REFERENCES}

1. Tapias MA, Jimenez-Garcia R, Lamas F, Gil AA. Prevalence of traumatic crown fractures to permanent incisors in a childhood population: mostoles, Spain. Dent Traumatol. 2003;19(3):11922. doi: 10.1034/j.1600-9657.2003.00141.x

2. Singi $T$, Tanaka EH, Koren M, Minami $P$, Honda $M$, Guedes $A$. Reanatomização estética anterior usando a técnica da barreira lingual de silicona e mock-up. Rev APCD/SBC. 2011;(72):13-6.

3. Castro MAM, Castro JCM, Pedrini D, Panzarini SR, Poi WR. Diastemas: restabelecimento da harmonia do sorriso. RGO - Rev Gaúch Odontol. 2010;58(2):253-6.

4. Donly KJ, Browning R. Class IV preparation design for microfilled and macrofilled composite resin. Pediatr Dent. 1992;14(1):34-6.

5. Villarroel MA, Hirata R, de Souza AM. Avaliação comparativa da translucidez do esmalte dentário e de resinas compostas para esmalte. Rev Dental Press Estét. 2005;2(3):22-34.

6. Felippe LA, Monteiro S Jr, De Andrada CA, Di Cerqueira AD, Ritter AV. Clinical strategies for success in proximoincisal composite restorations. Part I: understanding color and composite selection. J Esthet Restor Dent. 2004;16(6):336-47. doi: 10.1111/j.1708-8240.2004.tb00065.x

7. Correia A, Oliveira MA, Silva MJ. Conceitos de estratificação nas restaurações de dentes anteriores com resinas compostas. Rev Portug Estomatol. 2005;46(3):171-8.

8. Marturelli R, Cavalcanti NM, Souza FB, Porto POB, Silva CHV. Alternativa estética para reconstrução de dentes anteriores fraturados. Stomatos. 2007;13(25):123-30.

9. Baratieri LN, Monteiro Junior S, Correa M, Ritter AV. Posterior resin composite restorations: a new technique. Quintessence Int. 1996;27(11):733-8.

10. Chimeli TBC, Vale Pedreira APR, Souza TCP, Maciel M, Paula LM, Garcia FCP. Tratamento restaurador de diastemas anteriores com restaurações diretas em resina composta: relato de caso. Rev Dent. 2011;10(20):54-7.

\section{Collaborators}

LL VALENTE wrote the case report and participated in the preparation of the proposal and literature review. EA MÜNCHOW and SL PERALTA participated in the literature review and helped write the case report. NC SOUZA mentored all stages of this case and proofread the final version of the article.

11. Xavier CB, Faria GD, Vogt BF, Collares KF, Dickel R. Estudo dos traumatismos alvéolo-dentários em pacientes atendidos em um Setor de Cirurgia e Traumatologia Buco-Maxilo-Facial. RGO Rev Gaúcha Odontol. 2011;59(4):565-70.

12. Martins PWD, Silva MGS, Torre EN, Baldissera RA, Silveira LFM, Cruz LERN, et al. Reabilitação estética em dentes anteriores com lesões de cárie proximais: relato de caso. Odontol Clín-Clent. 2011;10(3):293-5.

13. Clavijo VGR, Kabbach W, Villarroel M, Andrade MF, Cândido MS. Restaurações anteriores - bisel: até que ponto sua utilização é viável? Rev Dental Press Estét. 2007;4(3):24-33.

14. Ozel E, Karapinar-Kazandag M, Soyman M, Bayirli G. Resin composite restorations of permanent incisors with crown fractures: a case report with a six-year follow-up. Oper Dent. 2011;36(1):112-5. doi: 10.2341/10-135-TR

15. Coelho-de-Souza FH, Rocha Ada C, Rubini A, Klein-Junior CA, Demarco FF. Influence of adhesive system and bevel preparation on fracture strength of teeth restored with composite resin. Braz Dent J. 2010;21(4):327-31. doi: 10.1590/S010364402010000400007

16. Mizuno SK. Efeito do bisel na infiltração marginal em restauração classe IV de resina composta. Bauru: Universidade de São Paulo; 2003.

17. Figueiredo RJA, Andrade AKM, Duarte RM, Medeiros e Silva FDSC. Otimizando a estética por meio de reanatomizações em dentes conóides. RGO - Rev Gaúch Odontol. 2008;56(3):333-6.

18. Puckett AD, Fitchie JG, Kirk PC, Gamblin J. Direct composite restorative materials. Dent Clin North Am. 2007;51(3):659-75. doi:10.1016/j.cden.2007.04.003 
